\title{
UNIVERSITYOF
}

FORWARD

THINKING

WESTMINSTER用

WestminsterResearch

http://www.westminster.ac.uk/westminsterresearch

\section{Strategic Alliances and Firm Performance in Startups with a} Social Mission

Cacciolatti, L., Rosli, A., Ruiz-Alba, J. and Chang, J.

NOTICE: this is the authors' version of a work that was accepted for publication in Journal of Business Research. Changes resulting from the publishing process, such as peer review, editing, corrections, structural formatting, and other quality control mechanisms may not be reflected in this document. Changes may have been made to this work since it was submitted for publication. A definitive version was subsequently published in the Journal of Business Research, 106, pp. 106-117, 2020.

The final definitive version in Journal of Business Research is available online at: https://dx.doi.org/10.1016/j.jbusres.2019.08.047

(C) 2020. This manuscript version is made available under the CC-BY-NC-ND 4.0 license https://creativecommons.org/licenses/by-nc-nd/4.0/

The WestminsterResearch online digital archive at the University of Westminster aims to make the research output of the University available to a wider audience. Copyright and Moral Rights remain with the authors and/or copyright owners.

Whilst further distribution of specific materials from within this archive is forbidden, you may freely distribute the URL of WestminsterResearch: ((http://westminsterresearch.wmin.ac.uk/)).

In case of abuse or copyright appearing without permission e-mail repository@westminster.ac.uk 


\title{
Strategic Alliances and Firm Performance in Startups with a Social Mission
}

\author{
Luca Cacciolatti* \\ University of Westminster \\ 35 Marylebone Road \\ London, NW1 5LS \\ l.cacciolatti@westminster.ac.uk \\ Ainurul Rosli \\ Brunel University \\ Kingston Lane, \\ London, Uxbridge, UB8 3PH \\ ainurul.rosli@brunel.ac.uk \\ José L. Ruiz-Alba \\ University of Westminster \\ 35 Marylebone Road \\ London, NW1 5LS \\ j.ruizalbarobledo@westminster.ac.uk \\ Jane Chang \\ Coventry University \\ 109-117 Middlesex St, \\ London, E1 7JF \\ ad0614@coventry.ac.uk
}

Accepted in Journal of Business Research: 31 August 2019.

*Corresponding author 


\section{Strategic Alliances and Firm Performance in Startups with a Social Mission}

Innovation with a social purpose is strictly linked to entrepreneurship and economic development. However, those startups that pursue a social mission often operate in really novel markets and raise some scepticism in the eyes of investors. Startups can improve their business performance by leveraging on equity and non-equity based strategic alliances, so to pursue growth. However, sustainable growth requires to attract the right investments at the right stage of development of the startup. This study draws on international business theory and proposes a novel framework that explains the mechanisms regulating strategic alliances and firm performance in a startups context. We use a sample of 3,913 UK high-tech startups engaging in social innovation to test our hypotheses and we derive an explanation for some of the mechanisms behind strategic alliances effect on startups performance, startups scalability and the balance needed between performance and the pursuit of a social mission.

Keywords: strategic alliances, accelerators, startups, social innovation, fundraising, joint ventures 


\section{Introduction}

In the UK, $5.7 \mathrm{~m}$ small businesses contribute to $£ 1.9$ trillion of turnover and employ 16m people (UK Government, 2019). A recent report from the British Council (2019) highlighted the increase of social enterprising activity in the UK, which contributes to the UK economy with $£ 24$ bn per year across economic sectors. Social enterprises operate in any industry of the UK economy and the government gives them increasingly higher attention and 'have introduced a number of initiatives to support the sector's growth. This has resulted in financial support and legislation to make the business environment more favourable for social enterprises' (2019, p. 49).

As authors of this study, we believe the scope of the definition of social enterprises is currently too narrowly focusing only on not-for-profit organisations, neglecting the social mission embedded in many for-profit organisations. Social enterprises are generally defined as businesses 'with primarily social objectives whose surpluses are principally reinvested for that purpose in the business or in the community, rather than being driven by the need to maximise profit for shareholders and owners' (DTI, 2002), but it is often difficult to obtain a crisp definition of social enterprises based on social purpose. For instance, a lot of for-profit organisations engage in social innovation (Altuna et al., 2015) thus, these also have a social purpose without necessarily being classified as social enterprises. These enterprises have been defined as 'for-profit social ventures', as they have been incorporated as for-profit bodies, but they have been designed to serve a social purpose (Dees \& Anderson, 2003).

Likewise, a lot of social enterprises do not engage in social innovation, despite their focus on sustainability (Yunus et al., 2010). Furthermore, social innovation is cross-sectoral (Murphy et al., 2012) as it involves public and private stakeholders (the latter, in both forprofit and not-for-profit companies), and, thereby, attracting the interest of governmental and supra-governmental bodies. For instance, the European Union 'acts as an agenda-setter in the 
measurement of social innovation, working with and liaising with the private sector, venture capitalists, and foundations to facilitate a consensus' (European Commission, 2012, p. 15).

Enterprises, to deliver on social mission goals without lessening their business performance, have to leverage the collaborations that often occur in spontaneous entrepreneurial and innovation ecosystems (Letaifa \& Rabeau, 2013). This is particularly true for startups, which lack resources and social capital (Lonial \& Carter, 2015). Given the stress caused by limited resources, collaborations amongst startups have to be strategic in nature and different types of alliances can take shape between startups and their partners according to their different strategic alignments (Herrera, 2015).

Business-to-business (B2B) strategic alliances can provide solutions to societal challenges (Chesbrough \& Bogers, 2014; Phillips et al., 2015) while enhancing the startups' business performance. Furthermore, social enterprises are at the core of value creation: these can create value for the society at large by leveraging collaborations and strategic alliances with non-for-profit organisations primarily, but with for-profit firms, too. Such collaborations and alliances enable the development of strategies that foster social innovation (Felício et al., 2013). These alliances directly benefit communities, individuals, and society overall.

However, it is important to highlight that these relationships are also beneficial for those firms that engage in these relationships (Drumwright, 2014), as there is evidence of the economic benefit for for-profit firms to engage in social innovation practices (Shaw \& de Bruin, 2013; Ozdemir et al., 2017).

Notwithstanding the extensive research on strategic alliances and the importance of alliances to the success of firms operating within a social mission frame, there is still lack of understanding of how alliances impact the performance of those firms that decide to adopt a social mission and which engage in innovation for the benefit of society. 
In a startup context, a strategic collaboration consists of collaborating on both core and non-core activities so as to enhance the competitive advantage of the startup. Quite often, startups capitalise on alliances through external funding from investors to boost their financial performance (Parker et al., 2010). Funding enables the firm to grow and pass through the successive stages of development from seed funding to venture growth and to finally exit through merger and acquisition.

Most of the studies on strategic alliances focus on multi-national enterprises (MNEs), mergers, acquisitions, differentiation, cost leadership (Culpan, 2009), alliances of ecommerce (Park et al., 2004), partnership reputation (Li et al., 2008), and governance and structure (Teng \& Das, 2008). The startups' context has been neglected in the extant literature. There are only a few studies investigating the link between strategic alliances and startups performance (Chang, 2004). There have been some attempts to investigate strategic alliances in an SME context; in that sense, Franco and Haase (2015) developed a taxonomy for SMEs and classified four categories of strategic alliances: strategic, improvised, exploratory, and deliberate. Also, Swoboda et al. (2011) studied alliances' success factors in the context of small and medium-sized enterprises (SMEs).

That said, it is likely that relevance of strategic alliances for organisations' performance differs for MNEs and SMEs: Lunnan and Haugland (2008) investigated the factors that affected long-term and short-term performance and they suggested that alliance performance is a multidimensional construct. They showed that short-term performance can be explained by access to complementary resources and by the strategic importance of the alliance itself, while long-term performance is dependent on how the developmental process is handled by the partners.

On the other hand, startups differ from the latter due to their size, rate of development, use of business models innovation, use of social capital and market focus 
(Brouthers \& Nakos, 2004; Van de Vrande et al., 2009). Hence, how do strategic alliances impact startups performance? What strategic alliances may startups benefit from at different stages of their business development? Furthermore, a lot of startups also have a strong social orientation and pursue a social mission (Hockerts, 2006). This social mission is often the trigger of their business operations and sometimes it leads to the development of social innovations and other disruptive market solutions to societal problems (Mirvis et al., 2016).

The main objectives of the paper are (i) to explore the relationship of strategic alliances with firm performance, and (ii) how different stages of firms' business development influence strategic alliances' and firms' performance.

These are important questions that we address in this paper, as it investigates the relationship between strategic alliances and startup performance, with particular focus on credit rating and Earnings Before Interest, Taxes, Depreciation, and Amortization (EBITDA). We also study the moderating effect of the stage of development of the startup on the alliance-performance relationship by keeping in focus whether startups have a social mission.

The theoretical contribution to this paper is twofold: First, this paper contributes to the emerging theories of social innovation by adding to this growing body of literature a strategic dimension of social innovation collaborations. Second, this paper contributes to the current debate on strategic alliances by exploring different types of alliances among startups such as equity, non-equity based alliances, joint ventures, and hybrid alliances. By means of this study we, we enrich current innovation theory by explaining how different forms of startups alliances benefit startup performance. We also contribute to international business theory on strategic alliances and shed light on the role of strategic alliances amongst startups and fill the gap left by the lack of studies on strategic alliances in the context of startups with a social mission. We propose a new, startup specific framework that explains how equity and non-equity alliances affect startups' business performance at different stages of business 
development and how these mechanisms differ from a more multinational-enterprises-based (MNEs) context.

In this study, we draw upon the literature on social innovation, business strategy, and international business to derive some hypotheses. We propose a framework for startup strategic alliances based on international business theory (which is mostly focused on MNEs) and we test the hypotheses with a dataset of high-growth UK startups using a sample of 3,913 firms. The extant literature on this topic shows varied results, and often do not cover more than one type of alliance in a single study. This paper extends current theory on strategic alliances within a startup context by adding to the clarity on how different types of startup alliances affect startup performance at different stages of development. The findings show that traditional theories on strategic alliances for MNEs do not necessarily apply to the dynamic, resource-scarce, and challenging world of startups.

This paper is structured as follows: Section 2 introduces the conceptual framework, section 3 introduces the methodology, section 4 describes the analysis and results, in section 5 the results are discussed, section 6 considers the implications for practitioners, and section 7 presents the conclusion. 


\section{A Framework for Strategic Alliances and Startup Performance}

\subsection{The Role of Strategic Alliances in Enhancing Firm Performance Amongst Startups}

Strategic alliances contribute to the firm's competitive advantage by determining performance outcomes (Baum et al., 2000; Musarra et al., 2016). The different types of collaborations and partners involved in strategic alliances enable startups to build trust and credibility (Jiang et al., 2015), and to grow their markets (Park et al., 2002). Empirical research on the relationship between strategic alliances and firm performance has so far been inconclusive (Baum et al., 2000; Rothaermel \& Deeds, 2004). Some alliances benefit the organisations, while others are detrimental to startups' development (Lerner et al., 2003). For instance, some studies demonstrate that startups are better off alone (Rosenbusch et al., 2011), and others do not discount collaborations but point out the risks associated with that (Hagedoorn et al., 2018). In light of the inconsistencies amongst the results from previous studies, we posit that strategic alliances benefit startups' financial performance, but the type of alliance may have different effects. For instance, equity options (e.g., fundraising), nonequity options (e.g., grants), joint venture programmes (e.g., university spin-offs), and hybrids combination (e.g., accelerators' attendance) may all contribute to financial performance in different ways.

Equity and non-equity. The literature on startup alliances also suggests that there are major differences between equity and non-equity based alliances (Das \& Teng, 2000). More importantly, Parker et al. (2010) show that non-equity alliances, such as grants from the public sector are attractive to startups seeking resource complementarity and to improve market access (Hess \& Rothaermel, 2011). 
Equity options such as fundraising are sought after by startups because this type of alliance has great potential to boost growth (Plummer et al., 2016). However, this type of alliance requires the startup to give up some equity against the investment poured into the firm: 'Equity financing in entrepreneurship primarily includes venture capital, corporate venture capital, angel investment, and crowdfunding' (Drover et al., 2017, p. 1820). Although this type of funding drives startups growth, it also entails significant risk because it can be limiting for the firm as it can cause conflicts over goals which interfere with the overall performance.

Non-equity options, such as grants are used by venture capitalists as an indicator of technological competence and thus increase confidence in the startup and her ability to make a transition from concept to market (Fisher et al., 2016). It reflects the endorsement by public organisations and it can be used by the startup to increase its legitimacy and attract highquality partners (Dacin et al., 2007). Subsequently, this influences their financial performance (Wang et al., 2017), for instance, startups obtaining governmental grants are more likely to attract venture capital investments (Islam et al., 2018). Startups often lack historical data to back-up their potential at the seed-funding stage and for them showing evidence of $R \& D$ funding fortifies their reputation and increases their commercial attractiveness (Capaldo, 2014) suggesting to investors that the startup's offering is valuable and it is financially solid (Wang et al., 2017).

Joint ventures and hybrid alliances. Notwithstanding the importance of equity and non-equity based alliances, other collaborative forms such as joint ventures benefit startups by leveraging on social capital. For instance, university spin-offs are strategic alliances that equip startups with the tools to manage extended relationships with universities and their stakeholders, thus leveraging on universities reputation and social capital (Walter et al., 2006). Furthermore, startups' and universities' joint ventures often inherit resources from the 
university such as machinery, equipment, knowledge, and expertise (Garnsey et al., 2008), although the effects of a joint venture on performance are mitigated by the firm's stage of development (Haeussler et al., 2012). Other forms of alliances are hybrid in nature, as they are a combination of equity and non-equity based forms of collaboration (Reuer et al., 2016). For instance, accelerators provide access to pre-seed investment, to the market, a supportive peer-to-peer environment for know-how exchange, access to each other's networks which include other firms, investors, mentors and alumni of the accelerator (Pauwels et al., 2016). Despite the resource investment of accelerators into startup programmes, accelerators do not always ask for equity in exchange of their services, but their relationship with startups is often based on in-kind contributions that add value to different cohorts of startups (Hagedoorn et al., 2018). Current literature displays disagreement on whether hybrid alliances are beneficial for startups' performance though some studies support their usefulness (Goswami et al., 2018).

Thus, in light of what has been discussed so far our nested hypothesis is:

H1: Strategic alliances have a direct and positive effect on firms' performance:

H1.1: Equity-based alliances have a direct and positive effect on firms' performance;

H1.2: Non-equity-based alliances have a direct and positive effect on firms' performance;

H1.3: Join ventures have a direct and positive effect on firms' performance;

H1.4: Hybrid alliances have a direct and positive effect on firms' performance. 


\subsection{The Moderating Effect of Startups' Stage of Development on the Strategic Alliances- Firm Performance Relationship}

Startups always face the challenge of funding their development at any stage of their lifecycle (Puri \& Zarutskie, 2012). At each stage of development, startups need different kind of financial support from different types of investors, e.g. angel investors or universities' endowment for seed funding, venture capitalists for venture growth, and investment from larger enterprises for exit through merger s and acquisitions. Current literature shows that different types of alliances attract different types of investment and, as a consequence of this, the pathway ahead for the startup is laid: 'Venture capitalists provide returns to their limited partners within ten or so years, there is often a focus on realizing a timely exit via an acquisition or initial public offering (IPO)' (Drover et al., 2017, p. 1821).

In the current literature it is evident that during different stages of development, startups need to get established in the market and teaming up at an early stage with accelerators, angel or venture capital investors accelerates their achievement of performance key milestones (Hathaway, 2016).

Strategic alliances do contribute to performance (Rosenbusch et al., 2013), but given the diversity of startup needs during their lifecycle, it is likely that the stage of development of the startup plays a moderating role on the relationship between strategic alliance and firm's performance. The legitimisation that a startup obtains by partnering with venture capital firms serves as a catalyst for future investments at the further stages of development and provides a base for future performance (Picken, 2017). Thus, we hypothesise:

H2: The stage of development of the firm moderates the relationship between strategic alliances and firm performance. 


\subsection{Social Innovation and Firm Size as Performance Drivers}

Social innovation is a novel solution (Phills et al., 2008) to problems. More specifically, it is an innovative solution to complex environmental, economic and societal challenges, and it aims to increase societal welfare through co-creation (Borzaga \& Bodini, 2014). Social innovation 'relates to system-innovation, game changers and narratives of change' (Avelino et al., 2017, p. 2) and it requires the creation and application of new knowledge that leads to new capabilities amongst diverse stakeholders (Voorberg et al., 2015). Therefore, social innovation is at the core of the creation of a long-lasting system (Marques et al., 2018) which aims to address societal needs while promoting multi-actor collaboration (van Wijk et al., 2018). Social innovation is not only a game-changer for the communities that benefit from its action but also a tool for startups to position themselves in the market and drive performance (Avelino et al., 2017). It is accepted wisdom that firms with a social mission also have a competitive advantage because they 'elicit economic validity' (Muñoz \& Kimmitt, 2018, p. 1). However, the difficulty of balancing between social mission and economic objectives has already been acknowledged in the literature (Doherty et al., 2014). The relationship between social innovation and firm performance is therefore acknowledged in the literature: Enterprises that engage in a social mission increase their value as a consequence of enhanced customer loyalty, improved reputation and higher retention of key stakeholders (Adhikari, 2016; Herrera, 2016). Furthermore, public awareness about the social mission of the firm is associated with increased firm value (Servaes \& Tamayo, 2013).

Startups with a social mission attract social venture capital; its funding decision rules are unique 'because of the dual organizational identities of the ventures that they assess... [and] the attributes unique to social ventures such as social mission, an entrepreneur's passion for social change, and community-based network are critical assessment factors' 
(Miller \& Wesley, 2010, p. 706). Furthermore, an organisation's self-definition determines its actions and an organisation's mission influences business performance (Bart et al., 2001). Firms that pursue a social mission are more inclined to have stronger entrepreneurial leadership and display better performance when marketing capabilities are developed, to the point that in previous studies some entrepreneurial ventures developed their traditional business models into business-like social enterprises, increasing their overall performance (Liu et al., 2015).

Given the increased credibility of firms engaging in social missions, it is reasonable to hypothesise that the engagement of the startup in social innovation leads to higher financial performance. Thus,

H3: Startups operating in the social innovation domain are associated with better firm performance.

Likewise, research shows the firm size to be an essential determinant of performance (Orser et al., 2000). It is associated to higher flexibility at adapting to changes in the market (Carayannopoulos, 2017), but in the current literature, firm size has also been proved to be associated to poor firm performance, e.g. decreased profitability during crises (Bartz \& Winkler, 2016). In spite of some enhanced flexibility, smaller organisations seem not to be able to capitalise on the scaling effect that larger organisation benefit from (Lonial \& Carter, 2015). This is particularly important to startups, given their very small size. However, there are a number of startups that have gone rapidly through various stages of development without forming an alliance, e.g. unicorns, which reach high valuations in a very short time (Coad et al., 2014). Overall, it is common sense to believe that the larger the organisation the better is the availability of resources. Thus, we assume the same type of relationship between 
size and performance should be observed in startups. Therefore, we control our model by size and we hypothesise that:

H4: Larger firm size is associated with better firm performance.

INSERT FIGURE 1 ABOUT HERE 


\section{Methodology}

This study adopts a quantitative approach to data collection and analysis. The hypotheses were tested by means of data coming from a population of UK startups. Although different industries were represented in the population, we focused on high-tech startups operating in different industries. In what follows, we report the measures, data collection process, sampling method, and sample description.

\subsection{Measures}

Dependent variables. In this study, performance is measured by two variables, which are (i) Credit Rating and (ii) EBITDA. We chose these variables so as to obtain a measure of performance based on the startups' attractiveness to investors. Although venture capitalists and angel investors value the background of the founder and the composition of the team (Bellavitis et al., 2018), once they are satisfied with the team they look thoroughly into the financial performance of the startup.

Credit rating is measured by the firm's credit rating in the year 2017. For those startups that participated in the accelerator's programme, the credit ratings have been measured after they entered the programme. For all those companies that did not take part in an accelerator's programme, the credit rating has been measured at the point of valuation. Credit rating has become ' the standard tool used by lenders in determining who should receive funding, at what rate, and under what conditions' (Spader, 2010). Furthermore, credit rating has previously been used in studies about startups and their performance, particularly as a proxy for access to external finance geared towards growth (Czarnitzki et al., 2014). Credit rating is an important measure of performance for a startup, as it reflects the creditworthiness of the new business entity and is used by credit lenders to evaluate the performance prospects of the startup (Cole \& Sokolyk, 2018). 
EBITDA, the last measure of performance is a direct measure of profitability, as it represents the operating profit before non-operating expenses. This measure of profitability is particularly reliable because it eliminates the influence of financing and accounting decisions from the measurement of profitability (Bertrand, 2009). Profitable organisations are attractive to investors because profitability demonstrates their financial capabilities and the viability of their business operations (Boyett \& Currie, 2004). We compared (pre-tax) Profit with EBITDA to see whether this would make a difference. It was found that there was no significant difference in terms of the magnitude of the effect on the standardised coefficients of the linear regression model. Therefore, we decided to settle for EBITDA as the measure of profitability for the purpose of this study.

Independent variables and moderator. In this study, we use the type of strategic alliance sought by the startup as a predictor of performance. Strategic alliances are measured through different proxies of collaboration. In line with the alliance continuum, we have independent variables that cover all four types of alliances. These are hybrid types (e.g. accelerators' attendance), joint ventures (e.g. university spin-offs), equity options (e.g. fundraising), and non-equity options (e.g. grants), and these are measured as follows.

Accelerator. This variable indicates the number of months the startup spent in an accelerator's programme. This variable reflects the partnership between the startup and the accelerator and it measures the length of engagement with the accelerator. The length of a partnership is particularly important in this context because, unlike standard partnerships on the alliance continuum, which assume either a non-equity or an equity option, the partnership between a startup and an accelerator is more like a hybrid alliance (Reuer et al., 2016). Accelerators sometime obtain (but not always) some equity in exchange for the access to a structure that enables intense interactions amongst cohorts; a structure that monitors education and offers time-limited support to enable rapid progress. Some examples of this 
support include access to pre-seed investment, access to market, a supportive peer-to-peer environment for the exchange of know-how, access to networks of a community made of firms, investors, mentors, and alumni of the accelerator (Pauwels et al., 2016).

Spin-off. This variable indicates whether the startup is a university spin-out. It is a dummy variable with values $0-1$. Spin-offs are a form of joint ventures between universities and private entities mostly based on joint ownership of the Intellectual Property Rights (IPR) (Wright et al., 2006). Joint ventures between universities and private firms are important to leverage access to finance because they are rare and provide a strong investment incentive to venture capitalists for their access to universities' resources such as economic support, knowhow, and reputation capital (Clarysse et al., 2005).

Fundraising. This variable measures fundraising. Fundraising is related to the concept of venture capital funding and it consists of private investors' investment in privately held companies (Jeng \& Wells, 2000). It is measured in term of the number of fundraisings (fundraisings_no) and fundraising value (fundraisings_value). Venture capitalists have a tendency to repeat their investment when the firm is successful. Thus, the number of fundraisings the firm participates in is important. Also, the value raised is important because fundraising activity per se acts as a "facilitator to the raising of both follow-on and larger funds' (Milosevic, 2018, p. 49). Fundraisings are a form of collaboration based on equity sharing, as venture capitalists are ready to invest in a startup when they foresee a return on their investment.

Grants. These are associated with support money received from national sources that link to R\&D and innovation. Thus, '[They are] beneficial [to firms] in boosting their innovative performance... [and to] finance substantial pre-competitive R\&D’ (Romijn \& Albaladejo, 2002, p. 1064). Grants are measured in terms of the number of grants (grants_no) and overall value (grants_value). The relationship between grants and the potential for 
venture capital investment that follows grants has been demonstrated (Islam et al., 2018), as often startups do not have historical data to back-up their potential. Grants are used by venture capitalists as an indicator of technological competence and, therefore, increase their confidence in the startup and the startup's ability to make the transition from concept to market (Fisher et al., 2016).

Stage of development. This variable is associated with the business stage of development (business_stage) and it is split into the following qualitative categories: (a) zombie or dead, i.e. those firms that have been wound up or do not display any activity and, therefore, shut down by Companies House - the UK's registrar of companies - (b) seed, i.e. those firms that already obtained seed funding, (c) growth, i.e. those firms that have already obtained some growth funding, (d) venture, i.e. those firms that have received venture capital funding, and (e) exited, i.e. those firms that have exited by merges and acquisitions.

Controls. Social innovation. Current literature on socially responsible investment (SRI) clearly states that SRI has become mature practice and investors are now used to invest in socially responsible firms (Trinks \& Scholtens, 2017). Under the assumption that a startup that engages in societal challenges is more attractive to investors (Arena et al., 2018), we include a measure of social innovation in our models. Social Innovation is measured by a 0-1 dummy variable indicating whether the startup pursues social innovation activities or operates within a socially-relevant industry. By the latter term, we mean industries whose main purpose is social improvement, although we acknowledge that any industry could potentially and indirectly have social relevance. Examples of industries that are driven by socially-relevant innovation are those that are in Education technology (EdTech), clean energy, and preventive healthcare to mention a few. A comprehensive list of the industries is given in Appendix A. This measure is currently used in studies of social innovation and social entrepreneurship. It is operationalised by either capturing social innovation in terms of 
the company's involvement with innovative activities and services that are motivated by the goal of meeting social needs (Cajaiba-Santana, 2014), or by the values that underpin 'the social and economic missions of the organisation' (Stevens et al., 2015). This is embodied by the firm's ability to propose innovative products, services or business models that foster social, economic and environmental sustainability. More precisely, to determine whether an enterprise engages in social innovation, we followed the social innovation criteria and measurement framework proposed by the European Commission (Bund et al., 2013), which takes into account of nine elements. Of these, the more important are the newness of the proposed social solution, the probability of the solution fulfilling the relevant social need, the legitimacy of the social need, and its urgency.

Firm size. Although startups are often very small, even for startups size matters. Larger startups have access to better resources and it is a measure of the magnitude of their operations and the scope of their sales. Furthermore, there is evidence that large size is associated with lower agency risk, i.e. managers will act in the best interest of the company's stakeholders, which would result in higher credit rating (Ashbaugh-Skaife et al., 2006).

\subsection{Data Collection, Sample Selection and Description}

To test the proposed hypotheses, we used the data available from a platform called Beauhurst ${ }^{1}$. This database comprises over 35,000 UK startups and includes different variables related to mergers, acquisitions, investments, fundraisings and joint ventures in general. The dataset was accessed online on $20^{\text {th }}$ September 2018. The sample was selected by stratified random sampling. To determine the sampling strata, the following criteria were applied. The rationale for the use of stratified random sampling method was to minimise sampling error to obtain lower sub-strata mean differences between the sample and the overall population. The

\footnotetext{
${ }^{1}$ www.beauhurst.com
} 
criteria and their selection rationale were: (i) business stage of development, (ii) firm size, (iii) gender of the founders, (iv) number of fundraisings, (v) number of grants. We also included all startups that were engaged in social innovation $(n=772$, this sub-sample accounts for $20 \%$ of our sample). The process resulted in a sample of 3,913 startups. The following table summarises the sample description.

INSERT TABLE 1 ABOUT HERE

\section{Analysis and Results}

\subsection{Models Specification and Data Analysis}

The data were analysed by means of multiple linear regression analysis with the coefficient estimation algorithm method 'Enter'. Four equations were specified: Two equations tested the direct effect of models and two others tested the interaction effects. The dependent variables for all models are credit rating and EBITDA.

Multicollinearity. The variables to be included were firstly screened by means of correlation analysis (see Appendix B), which showed only $20 \%$ of the variables were highly correlated, i.e. only a few variables had statistically significant correlations with coefficients equal to, or higher than .6. The small number of highly correlated variables was not a cause of concern in the presence of multicollinearity. This has been confirmed later on, case by case, by the calculation of the tolerance (TOL) and variance inflation factor (VIF) levels for each model, as shown in Tables 2 and 3.

Models specification. Two types of models were specified. The first type tested the direct effects of the predictors on the target variable and the second type tested the interaction effects between the predictors and the moderator on the target variable. Thus, for the direct 
effect models, we specified Model 1a which predicted credit rating. Model 1b, predicted profitability (measured by EBITDA). The interaction effects were measured with Models 2a and $2 \mathrm{~b}$, which predicted credit rating and profitability respectively.

Goodness-of-fit. Model 1a ( $\left.\mathrm{R}=.546, \mathrm{R}^{2}=.241, \mathrm{p}<.001\right)$ and Model 1b $(\mathrm{R}=.990$, $\left.\mathrm{R}^{2}=.933, \mathrm{p}<.05\right)$ fit the data very well showing an accuracy of prediction of $55 \%$ and $99 \%$, respectively. Model 1a only explained approximately $24 \%$ of the variance in credit rating, while Model $1 \mathrm{~b}$ explained about $93 \%$ of the variance in profitability. Likewise, when we look at the interaction effect models, we observe that Model $2 \mathrm{a}\left(\mathrm{R}=.354, \mathrm{R}^{2}=.117, \mathrm{p}<.001\right)$ and Model 2b $\left(\mathrm{R}=.987, \mathrm{R}^{2}=.968, \mathrm{p}<.001\right)$ fit the data very well, although Model 2a shows an accuracy of approx. $35 \%$.

\section{INSERT TABLES 2 AND 3 ABOUT HERE}

\subsection{Strategic Alliances' Effect on Startups Financial Performance}

The findings from regression Models $1 \mathrm{a}$ and $1 \mathrm{~b}$ are as follows. The value of fundraising activities is highly significant $(\mathrm{p}<.001){ }^{2}$ The overall credit rating of those startups which generate more money through fundraising increased by approx. 23\% (Beta=.234). Therefore, H1.1 is supported.

When we looked at the results related to profitability, i.e. EBITDA, all alliances-related predictors are significant ( $\mathrm{p}<.001)$, and this supports the nested hypotheses H1.1 to H1.4. While joint venture options such as spin-offs and non-equity options such as grants increased

\footnotetext{
${ }^{2}$ Please note: The adjusted R-squared is high for models $1 \mathrm{~b}$ and $2 \mathrm{~b}$. We estimated that although there is no multicollinearity overall (nor there is relative multicollinearity on the single items), the high correlation between firm size and fundraising value $(\rho=.716)$ may contribute to a slight inflation of the R-squared. Given the absence of multicollinearity in the models and given the theoretical support for the direction of the causality in the relationships being tested, we decided to keep both variables in order not to underspecify the model.
} 
profitability by approx. $51 \%$ and $16 \%$ respectively, we observed a negative relationship between other forms of alliance and profitability. In the cases of equity options, such as fundraising and hybrid options such as accelerators' attendance profitability decreased by almost 1.7 times and by $78 \%$, respectively.

\subsection{The Moderating Role of Startups' Stage of Development on the Relationship Between Strategic Alliances and Financial Performance}

The findings from regression Models $2 \mathrm{a}$ and $2 \mathrm{~b}$ are as follows. The interaction between startup stage of development and the value of fundraising activities is highly significant $(\mathrm{p}<.001)$ and those startups which are able to generate more money through fundraising at more advanced stages of development increase their overall credit by approx. $13 \%($ Beta=.126). This indicates that the hypothesis $\mathrm{H} 2$ is supported. Also, taking part in an accelerator's programme is beneficial to the startups at more advanced stages of development, increasing their profitability by $12 \%$.

When we look at the results related to profitability, i.e. EBITDA, those firms that obtain more grants at an advanced stage of development increased their profitability by approx. $15 \%$. On the other hand, raising capital through equity-options such as fundraising at more advanced stages of development decreased the firms' profitability considerably, i.e. to the order of 1.1 times.

\subsection{The Counterintuitive Effects of Social Innovation and the Healing Properties of Firm Size}

The findings related to social innovation are counterintuitive. Engaging in social innovation does not seem to have any effect on credit rating (i.e. the coefficients are nonsignificant). However, in the regression Model 1b, social innovation had a direct negative 
effect on profitability. Startups engaging in social innovation registered approximately $11 \%$ $(\mathrm{p}<.005)$ decrease in profitability. This supports the hypothesis H3.

On the other hand, firm size plays an important role in the prediction of the startup's credit rating and its profitability. Bigger startups showed an increase of $33 \%$ in profitability. Model 1a (direct effects) and by 18\% in Model 2a (interaction effects) and their effects are highly significant $(\mathrm{p}<.001)$. Likewise, firm size is associated with profitability $(\mathrm{p}<.001)$, and larger startups have about $76 \%$ higher profitability than smaller and, perhaps, startups that possess less resources. Thus, H4 is supported. 


\section{Discussion}

Startups' performance and funding options. Strategic alliances bring different advantages to startups. Our results show how different forms of alliance benefit startups' performance. Not all funding options have the same effect on startups' performance. While some strategic alliances such as non-equity alliances (e.g. spin-offs, grants) enhance profitability, others such as equity and hybrid alliances (e.g. fundraising, accelerators' programmes) hamper profitability but benefit credit rating.

It is interesting that, as regards equity and hybrid alliances, startups' access to finance through equity-based strategic alliances helps startups at an early stage of development (e.g. seed funding) by better credibility as perceived by investors. Thus, credible startups are able to access more finance by virtue of their improved credit rating. Investors seek for investment the firms that show the potential for growth so that their investments are not short-term. The investors do not focus on profitability in case of startups but on growth potential (Majumdar, 2010). In fact, during the early stages of development, startups do not earn profit and their net assets are often negative, especially amongst innovative startups (Söderblom et al., 2015). Despite these disadvantages, a better credit rating facilitates startups' access to finance. As our results show, equity options such as fundraising decrease their profitability. We can explain these findings with the fact that startups generally do not generate profit immediately after launch (Majumdar, 2010) and amongst startups' main goals are the mobilisation of resources and acquisition of knowledge (Mazloomi Khamseh et al., 2017) to generate revenue and improve efficiency (Hechavarría et al., 2016).

These findings are counterintuitive to the traditional logic on which international business strategies are based. These strategic alliances often lead to immediate profit through the acquisition of resources or market expansion (often through assets deriving from mergers and acquisitions). However, our findings on the effects of strategic alliances are in the 
context of startups and contribute a novel understanding of the relationship between strategic alliances and performance. The results of our study provide some insight into how startups with a social mission benefit from strategic alliances. However, we cautiously state that the results are generalizable only to the population of UK startups and we may not assume that startups with a social mission in different geo-socio-economic and political contexts may not behave in a different way.

With regards to non-equity alliances, in our study, we observed that spin-offs and grants have a positive effect on profitability. Unlike the previous type of alliances, where investors decide to invest in the startups based on their future potential, non-equity alliances are often leveraging on the social capital of their partners in the network in which they are embedded. Startups that receive grants 'attract more human and financial resources than others' (Söderblom et al., 2015, p. 1501). While equity investments provide the startups with enhanced leadership and strategic direction for their business development, the startups with non-equity investments leverage resources mobilisation through partners' networks (Walter et al., 2006).

Startups' alliances scaling effect. From the results of our analysis, we observed that the startups at an advanced level of development, i.e. at growth and venture funding stages, benefit from all strategic alliance options except the joint ventures. All these strategic alliances, such as hybrid (e.g., accelerators' engagement) and non-equity (e.g., governmental grants) have a positive effect on profitability. While these findings match somewhat with the expectations expressed in the literature on strategic alliances in the context of MNEs' context, this is the first time to the best of our knowledge, that the effects of strategic alliances have been tested on startups.

The startups develop from being micro-firms to SMEs and then into larger organisations going through the same stages and following a pattern of development very 
similar to that of larger organisations. However, the difference seems to be the tremendously greater pace of the startups' development as compared to that of the larger organisations.

This raises some questions on why the startup phenomenon seems to be so prominent nowadays as compared to the past when firms developed at more sedate pace. However, current literature emphasises startups' inability to capitalise on scaling effect (Lonial \& Carter, 2015) such as extra-resources complementarity and market access (Hess \& Rothaermel, 2011), which are typical of larger organisations, but our results show that startups can scale up through an enhanced profitability and enhanced credit rating if they engage in strategic alliances.

To this regard, the effects of equity alliances (e.g., fundraising) differ a bit in startups from MNEs. Due to the scale of their operations, the MNEs scale-up by attracting investments, e.g. raising share capital and obligations (for public companies) that are geared towards the expected profitability in the short-term. On the other hand, scalability through equity alliances in a startup context takes place through the enhanced credibility of the organisation from the investors' perspective.

Thus, investors do not invest in the startup because it is a 'winner', but rather because of the potential performance of the startup after the investor has ensured that the startup is well managed after the investment (Hellmann \& Puri, 2002). Our results show exactly that; that fundraising activities do have a positive effect on credit rating, but their relationship with profitability is negative. This enhanced credibility may reflect in the credit rating and enhance the startup's credibility in the eyes of investors. However, due to the small scale of the startups, it is often a gamble or a leap of faith for investors as there is no guarantee of an immediate return or enhanced short-term profitability. This is due to the lag effect of the increased cost of the scaling up that follows investment and the time it takes for the startup to capitalise on the increased turnover. Startups are often inexperienced and 'require substantial 
resources to fund the early stages of development' and their development projects are speculative. Therefore, 'revenues cannot be expected until well into the future' (Baum \& Silverman, 2004, p. 415).

The balance between social mission and business performance. In the results of our analysis, it can be observed that larger organisations (or bigger and more resourced startups) show higher profitability. Though some of the startups engaged in social innovation are comparatively large, they show lower profitability.

Given these results, we wonder whether pursuing a social mission is tilting against the windmills when it comes down to looking for investment opportunities. Or perhaps, is a pursuit of social mission the pursuit of a mirage for most and one that can be pursued only by larger organisations that do not generally have problems in earning a profit?

Those startups that generate social innovation are often struggling to get innovative solutions to societal problems that they generate accepted by the market. The meaning, value, and the usefulness of new products and services and business models sometimes create confusion (Lounsbury et al., 2003). This dichotomy between the expectations of business performance and serving a social purpose by the organisation requires to be balanced. This balance is often difficult to be found given the many challenges that surround the organisations that engage in social innovation. This dichotomy has already been observed in previous studies, which showed that the 'hybridity, the pursuit of the dual mission of financial sustainability and social purpose [...] creates tension' (Doherty et al., 2014, p. 417).

This tension is often solved either by abandoning the mission or continuing to show poor business performance. Thus, startups pursuing a social mission can maintain the balance between their social purpose and business performance only by establishing a good reputation, preserving it and performing consistently overtime (Pfarrer et al., 2010). This 
would gain them the confidence of their stakeholders and investors and facilitate their growth from one stage of development to the next (Baum \& Silverman, 2004). 


\section{Implications for Practitioners}

This study bears several implications for managers. First of all, it is important for startup founders and directors to be aware of the fact that taking part in an accelerator's programme is beneficial to the startups at more advanced stages of development - it increases their profitability by $12 \%$. Therefore, participating in accelerator's programme can improve the prospects for higher financial performance for such startups.

Second, startup founders may benefit from knowing that those firms that obtain more grants at an advanced stage of development can see their profitability increased by approximately $15 \%$. However, this good news comes with a potential catch twenty-two; for if they raise capital through equity-options, such as fundraising, this could decrease the profitability substantially for startups at more advanced stages of development. Thus, startup funders should calibrate their funding choices carefully at a more advanced stage of development. When a firm is growing fast and attracting funds to boost growth and seems a very attractive option, additional investing may backfire by badly impacting profitability.

Third, startups that are aiming to increase their credit rating should know that fundraising is a viable option to boost their credit rating by approximately $23 \%$. Therefore, the choice of investment sought for by the startup has a positive impact on credit rating, and this spirals into the future funding prospects of the startup.

Fourth, it is interesting for managers to know that spin-offs are the form of alliance with a higher positive impact on profitability. Therefore, the promotion of spin-offs by universities and other partner institutions should be a priority. This bit of information could also be used by policymakers by focusing their policy efforts on promoting coordination, and launching of more spin-offs. 
Fifth, when contemplating social innovation, managers should be cautious about the way they engage in it. From a business point of view, engaging in social innovation does not have per se a direct effect on credit rating, but social innovation may have a negative effect on profitability as shown in this study. Therefore, managers should be encouraged to engage in social innovation yet they should bear in mind the adverse effects of such engagement when planning for growth. They should be aware that they may encourage investment and engagement in social innovation and activities but they will not see an immediate, positive and direct impact on the profitability. Conversely, they will need to make an extra effort to see the impact of social innovation on their short term goals and fine-tune the effort to get the desired effects of social innovation on profitability in the mid- and long-term. 


\section{Conclusions}

This study developed a conceptual framework to explain how strategic alliances have an effect on startups' business performance. We developed several hypotheses based on the effects of equity- and non-equity-based strategic alliances at different stages of development of the startup. We controlled our study by size and by the engagement of the startup with social innovation because we hypothesised that the scope of the startups' operations and their focus on a social mission play a role in shaping their choice of the type of collaborations that they would engage in.

The questions that we wanted to answer were focused on how strategic alliances impact startups' performance and how and what strategic alliances may benefit the startups at different stages of their business development. We found that, unlike larger organisations' strategic alliances, startups operate in a peculiar way and different forms of equity- and nonequity-based alliances are not always appropriate at all stages of business development. Furthermore, for many startups, the focus on a social mission may hamper profitability in the short term although, in some cases, it improves the credibility of the firm in the eyes of the investors. It is paradoxical in a world that calls for more sustainable business and with governments that have social innovation at the top their agendas that larger organisations should seem better suited to engage in social missions. This is because the larger organisations' scope of operations enables them to profit from even those initiatives that may raise some scepticism among investors because the markets for those novel initiatives are still nascent. Notwithstanding the challenges that many startups pursuing a social mission have to face, if they can strike a balance between social mission and enhanced business performance they may yet leverage different forms of strategic alliance to build credibility, attract the 
attention of investors to obtain suitable funding and attain sustainable growth, though at the price of short term profitability. 


\section{References}

Adhikari, B. K. (2016). Causal effect of analyst following on corporate social responsibility. Journal of Corporate Finance, 41, 201-216.

Altuna, N., Contri, A. M., Dell'Era, C., Frattini, F., \& Maccarrone, P. (2015). Managing social innovation in for-profit organizations: The case of Intesa Sanpaolo. European Journal of Innovation Management, 18(2), 258-280.

Arena, M., Bengo, I., Calderini, M., \& Chiodo, V. (2018). Unlocking finance for social tech start-ups: Is there a new opportunity space? Technological Forecasting and Social Change, 127, 154-165.

Ashbaugh-Skaife, H., Collins, D. W., \& LaFond, R. (2006). The effects of corporate governance on firms' credit ratings. Journal of accounting and economics, 42(1-2), 203-243.

Avelino, F., Wittmayer, J. M., Pel, B., Weaver, P., Dumitru, A., Haxeltine, A., et al. (2017). Transformative social innovation and (dis) empowerment. Technological Forecasting and Social Change, 145(August), 195-206.

Bart, C. K., Bontis, N., \& Taggar, S. (2001). A model of the impact of mission statements on firm performance. Management Decision, 39(1), 19-35.

Bartz, W., \& Winkler, A. (2016). Flexible or fragile? The growth performance of small and young businesses during the global financial crisis—Evidence from Germany. Journal of Business Venturing, 31(2), 196-215.

Baum, J. A., Calabrese, T., \& Silverman, B. S. (2000). Don't go it alone: Alliance network composition and startups' performance in Canadian biotechnology. Strategic Management Journal, 21(3), 267-294.

Baum, J. A., \& Silverman, B. S. (2004). Picking winners or building them? Alliance, intellectual, and human capital as selection criteria in venture financing and 
performance of biotechnology startups. Journal of Business Venturing, 19(3), 411436.

Bellavitis, C., Kamuriwo, D. S., \& Hommel, U. (2018). Mitigation of moral hazard and adverse selection in venture capital financing: The influence of the country's institutional setting. Journal of Small Business Management.

Bertrand, O. (2009). Effects of foreign acquisitions on R\&D activity: Evidence from firmlevel data for France. Research Policy, 38(6), 1021-1031.

Borzaga, C. \& Bodini, R. (2014). What to make of social innovation? Towards a framework for policy development. Social Policy and Society, 13(3), 411-421.

Boyett, I. \& Currie, G. (2004). Middle managers moulding international strategy: An Irish start-up in Jamaican telecoms. Long Range Planning, 37(1), 51-66.

British Council. (2019). Social enterprise in the UK: Developing a thriving social enterprise sector. Retrieved. from

https://www.britishcouncil.org/sites/default/files/social_enterprise_in_the_uk_final_w eb_spreads.pdf.

Brouthers, K. D. \& Nakos, G. (2004). SME entry mode choice and performance: A transaction cost perspective. Entrepreneurship theory and practice, 28(3), 229-247.

Bund, E., Hubrich, D.-K., Schmitz, B., Mildenberger, G., \& Krlev, G. (2013). Blueprint of social innovation metrics - contributions to an understanding of opportunities and challenges of social innovation measurement. Brussels, Belgium: European Commission)

Cajaiba-Santana, G. (2014). Social innovation: Moving the field forward. A conceptual framework. Technological Forecasting and Social Change, 82, 42-51. 
Capaldo, A. (2014). Network governance: A cross-level study of social mechanisms, knowledge benefits, and strategic outcomes in joint-design alliances. Industrial Marketing Management, 43(4), 685-703.

Carayannopoulos, S. (2017). Small, young firm flexibility and performance in the context of disruptive innovations. International Journal of Entrepreneurship and Innovation Management, 21(1-2), 105-118.

Chang, S. J. (2004). Venture capital financing, strategic alliances, and the initial public offerings of Internet startups. Journal of Business Venturing, 19(5), 721-741.

Chesbrough, H. \& Bogers, M. (2014). Explicating open innovation: Clarifying an emerging paradigm for understanding innovation. In W. V. H. Chesbrough (Ed.), Open Innovation: New Frontiers and Applications (pp. 3-28). Oxford: Oxford University Press.

Clarysse, B., Wright, M., Lockett, A., Van de Velde, E., \& Vohora, A. (2005). Spinning out new ventures: A typology of incubation strategies from European research institutions. Journal of Business Venturing, 20(2), 183-216.

Coad, A., Daunfeldt, S.-O., Hölzl, W., Johansson, D., \& Nightingale, P. (2014). High-growth firms: Introduction to the special section. Industrial and Corporate Change, 23(1), $91-112$.

Cole, R. A. \& Sokolyk, T. (2018). Debt financing, survival, and growth of start-up firms. Journal of Corporate Finance, 50, 609-625.

Culpan, R. (2009). A fresh look at strategic alliances: Research issues and future directions. International Journal of Strategic Business Alliances, 1(1), 4-23.

Czarnitzki, D., Rammer, C., \& Toole, A. A. (2014). University spin-offs and the “performance premium”. Small Business Economics, 43(2), 309-326. 
Dacin, M. T., Oliver, C., \& Roy, J. P. (2007). The legitimacy of strategic alliances: An institutional perspective. Strategic Management Journal, 28(2), 169-187.

Das, T. K. \& Teng, B.-S. (2000). A resource-based theory of strategic alliances. Journal of Management, 26(1), 31-61.

Dees, J. G. \& Anderson, B. B. (2003). For-profit social ventures. International Journal of Entrepreneurship Education, 2(1), 1-26.

Doherty, B., Haugh, H., \& Lyon, F. (2014). Social enterprises as hybrid organizations: A review and research agenda. International Journal of Management Reviews, 16(4), $417-436$.

Drover, W., Busenitz, L., Matusik, S., Townsend, D., Anglin, A., \& Dushnitsky, G. (2017). A review and road map of entrepreneurial equity financing research: venture capital, corporate venture capital, angel investment, crowdfunding, and accelerators. Journal of Management, 43(6), 1820-1853.

Drumwright, M. E. (2014). Organizational congruence with socially responsible behaviors. In R. P. Hill \& R. Langan (Eds.), Handbook of Research on Marketing and Corporate Social Responsibility (pp. 91-107). Cheltenham: Edward Elgar.

DTI. (2002). Social Enterprise: A Strategy for Success. Retrieved. from.

European Commission. (2012). Strengthening Social Innovation in Europe: Journey to Effective Assessment and Metrics. Retrieved. from www.europa.eu.

Felício, J. A., Gonçalves, H. M., \& da Conceição Gonçalves, V. (2013). Social value and organizational performance in non-profit social organizations: Social entrepreneurship, leadership, and socioeconomic context effects. Journal of Business Research, 66(10), 2139-2146. 
Fisher, G., Kotha, S., \& Lahiri, A. (2016). Changing with the times: An integrated view of identity, legitimacy, and new venture life cycles. Academy of Management Review, 41(3), 383-409.

Franco, M. \& Haase, H. (2015). Interfirm alliances: A taxonomy for SMEs. Long Range Planning, 48(3), 168-181.

Garnsey, E., Lorenzoni, G., \& Ferriani, S. (2008). Speciation through entrepreneurial spinoff: The Acorn-ARM story. Research Policy, 37(2), 210-224.

Goswami, K., Mitchell, J. R., \& Bhagavatula, S. (2018). Accelerator expertise: Understanding the intermediary role of accelerators in the development of the Bangalore entrepreneurial ecosystem. Strategic Entrepreneurship Journal, 12(1), $117-150$.

Haeussler, C., Patzelt, H., \& Zahra, S. A. (2012). Strategic alliances and product development in high technology new firms: The moderating effect of technological capabilities. Journal of Business Venturing, 27(2), 217-233.

Hagedoorn, J., Lokshin, B., \& Zobel, A. K. (2018). Partner type diversity in alliance portfolios: Multiple dimensions, boundary conditions and firm innovation performance. Journal of Management Studies, 55(5), 809-836.

Hathaway, I. (2016, $1^{\text {st }}$ March). What startup accelerators really do. Harvard Business Review.

Hechavarría, D. M., Matthews, C. H., \& Reynolds, P. D. (2016). Does start-up financing influence start-up speed? Evidence from the panel study of entrepreneurial dynamics. Small Business Economics, 46(1), 137-167.

Hellmann, T. \& Puri, M. (2002). Venture capital and the professionalization of start $\square$ up firms: Empirical evidence. The journal of finance, 57(1), 169-197. 
Herrera, M. E. B. (2015). Creating competitive advantage by institutionalizing corporate social innovation. Journal of Business Research, 68(7), 1468-1474.

Herrera, M. E. B. (2016). Social innovation for bridging societal divides: Process or leader? A qualitative comparative analysis. Journal of Business Research, 69(11), 52415247.

Hess, A. M. \& Rothaermel, F. T. (2011). When are assets complementary? Star scientists, strategic alliances, and innovation in the pharmaceutical industry. Strategic Management Journal, 32(8), 895-909.

Hockerts, K. (2006). Entrepreneurial opportunity in social purpose business ventures. In Social entrepreneurship (pp. 142-154): Springer.

Islam, M., Fremeth, A., \& Marcus, A. (2018). Signaling by early-stage startups: US government research grants and venture capital funding. Journal of Business Venturing, 33(1), 35-51.

Jeng, L. A. \& Wells, P. C. (2000). The determinants of venture capital funding: Evidence across countries. Journal of Corporate Finance, 6(3), 241-289.

Jiang, X., Jiang, F., Cai, X., \& Liu, H. (2015). How does trust affect alliance performance? The mediating role of resource sharing. Industrial Marketing Management, 45, 128138.

Lerner, J., Shane, H., \& Tsai, A. (2003). Do equity financing cycles matter? Evidence from biotechnology alliances. Journal of Financial Economics, 67(3), 411-446.

Letaifa, S. B. \& Rabeau, Y. (2013). Too close to collaborate? How geographic proximity could impede entrepreneurship and innovation. Journal of Business Research, 66(10), 2071-2078. 
Li, D., Eden, L., Hitt, M. A., \& Ireland, R. D. (2008). Friends, acquaintances, or strangers? Partner selection in R\&D alliances. Academy of Management Journal, 51(2), 315334.

Liu, G., Eng, T. Y., \& Takeda, S. (2015). An investigation of marketing capabilities and social enterprise performance in the UK and Japan. Entrepreneurship Theory and Practice, 39(2), 267-298.

Lonial, S. C. \& Carter, R. E. (2015). The impact of organizational orientations on medium and small firm performance: A resource $\square$ based perspective. Journal of Small Business Management, 53(1), 94-113.

Lounsbury, M., Ventresca, M., \& Hirsch, P. M. (2003). Social movements, field frames and industry emergence: A cultural-political perspective on US recycling. Socio-economic Review, 1(1), 71-104.

Lunnan, R. \& Haugland, S. A. (2008). Predicting and measuring alliance performance: A multidimensional analysis. Strategic Management Journal, 29(5), 545-556.

Majumdar, S. (2010). How do they plan for growth in auto component business?'-A study on small foundries of western India. Journal of Business Venturing, 25(3), 274-289.

Marques, P., Morgan, K., \& Richardson, R. (2018). Social innovation in question: The theoretical and practical implications of a contested concept. Environment and Planning C: Politics and Space, 36(3), 496-512.

Mazloomi Khamseh, H., Jolly, D., \& Morel, L. (2017). The effect of learning approaches on the utilization of external knowledge in strategic alliances. Industrial Marketing Management, 63, 92-104.

Miller, T. L. \& Wesley, C. L. (2010). Assessing mission and resources for social change: An organizational identity perspective on social venture capitalists' decision criteria. Entrepreneurship Theory and Practice, 34(4), 705-733. 
Milosevic, M. (2018). Skills or networks? Success and fundraising determinants in a low performing venture capital market. Research Policy, 47(1), 49-60.

Mirvis, P., Herrera, M. E. B., Googins, B., \& Albareda, L. (2016). Corporate social innovation: How firms learn to innovate for the greater good. Journal of Business Research, 69(11), 5014-5021.

Muñoz, P. \& Kimmitt, J. (2018). Social mission as competitive advantage: A configurational analysis of the strategic conditions of social entrepreneurship. Journal of Business Research.

Murphy, M., Perrot, F., \& Rivera-Santos, M. (2012). New perspectives on learning and innovation in cross-sector collaborations. Journal of Business Research, 65(12), $1700-1709$.

Musarra, G., Robson, M. J., \& Katsikeas, C. S. (2016). The influence of desire for control on monitoring decisions and performance outcomes in strategic alliances. Industrial Marketing Management, 55, 10-21.

Orser, B. J., Hogarth-Scott, S., \& Riding, A. L. (2000). Performance, firm size, and management problem solving. Journal of Small Business Management, 38(4), 42.

Ozdemir, S., Kandemir, D., \& Eng, T.-Y. (2017). The role of horizontal and vertical new product alliances in responsive and proactive market orientations and performance of industrial manufacturing firms. Industrial Marketing Management, 64, 25-35.

Park, N. K., Mezias, J. M., \& Song, J. (2004). A resource-based view of strategic alliances and firm value in the electronic marketplace. Journal of Management, 30(1), 7-27.

Park, S. H., Chen, R., \& Gallagher, S. (2002). Firm resources as moderators of the relationship between market growth and strategic alliances in semiconductor startups. Academy of Management Journal, 45(3), 527-545. 
Parker, S. C., Storey, D. J., \& Van Witteloostuijn, A. (2010). What happens to gazelles? The importance of dynamic management strategy. Small Business Economics, 35(2), 203226.

Pauwels, C., Clarysse, B., Wright, M., \& Van Hove, J. (2016). Understanding a new generation incubation model: The accelerator. Technovation, 50, 13-24.

Pfarrer, M. D., Pollock, T. G., \& Rindova, V. P. (2010). A tale of two assets: The effects of firm reputation and celebrity on earnings surprises and investors' reactions. Academy of Management Journal, 53(5), 1131-1152.

Phillips, W., Lee, H., Ghobadian, A., O’Regan, N., \& James, P. (2015). Social innovation and social entrepreneurship: A systematic review. Group \& Organization Management, $40(3), 428-461$.

Phills, J. A., Deiglmeier, K., \& Miller, D. T. (2008). Rediscovering social innovation. Stanford Social Innovation Review, 6(4), 34-43.

Picken, J. C. (2017). From startup to scalable enterprise: Laying the foundation. Business Horizons, 60(5), 587-595.

Plummer, L. A., Allison, T. H., \& Connelly, B. L. (2016). Better together? Signaling interactions in new venture pursuit of initial external capital. Academy of Management Journal, 59(5), 1585-1604.

Puri, M. \& Zarutskie, R. (2012). On the life cycle dynamics of venture $\square$ capital $\square$ and non $\square$ venture $\square$ capital $\square$ financed firms. The Journal of Finance, 67(6), 2247-2293.

Reuer, J. J., Ariño, A., Poppo, L., \& Zenger, T. (2016). Alliance governance. Strategic Management Journal, 37(13), E37-E44.

Romijn, H. \& Albaladejo, M. (2002). Determinants of innovation capability in small electronics and software firms in southeast England. Research Policy, 31(7), 10531067. 
Rosenbusch, N., Brinckmann, J., \& Bausch, A. (2011). Is innovation always beneficial? A meta-analysis of the relationship between innovation and performance in SMEs. Journal of Business Venturing, 26(4), 441-457.

Rosenbusch, N., Brinckmann, J., \& Müller, V. (2013). Does acquiring venture capital pay off for the funded firms? A meta-analysis on the relationship between venture capital investment and funded firm financial performance. Journal of Business Venturing, 28(3), 335-353.

Rothaermel, F. T. \& Deeds, D. L. (2004). Exploration and exploitation alliances in biotechnology: A system of new product development. Strategic Management Journal, 25(3), 201-221.

Servaes, H., \& Tamayo, A. (2013). The impact of corporate social responsibility on firm value: The role of customer awareness. Management Science, 59(5), 1045-1061.

Shaw, E. \& de Bruin, A. (2013). Reconsidering capitalism: The promise of social innovation and social entrepreneurship? International Small Business Journal, 31(7), 737-746.

Söderblom, A., Samuelsson, M., Wiklund, J., \& Sandberg, R. (2015). Inside the black box of outcome additionality: Effects of early-stage government subsidies on resource accumulation and new venture performance. Research Policy, 44(8), 1501-1512.

Spader, J. S. (2010). Beyond disparate impact: Risk-based pricing and disparity in consumer credit history scores. The Review of Black Political Economy, 37(2), 61-78.

Stevens, R., Moray, N., \& Bruneel, J. (2015). The social and economic mission of social enterprises: Dimensions, measurement, validation, and relation. Entrepreneurship Theory and Practice, 39(5), 1051-1082.

Swoboda, B., Meierer, M., Foscht, T., \& Morschett, D. (2011). International SME alliances: the impact of alliance building and configurational fit on success. Long Range Planning, 44(4), 271-288. 
Teng, B.-S., \& Das, T. (2008). Governance structure choice in strategic alliances: The roles of alliance objectives, alliance management experience, and international partners. Management Decision, 46(5), 725-742.

Trinks, P. J. \& Scholtens, B. (2017). The opportunity cost of negative screening in socially responsible investing. Journal of Business Ethics, 140(2), 193-208.

UK Government. (2019). BEIS Small and medium enterprises (SME) action plan. Retrieved. from

https://assets.publishing.service.gov.uk/government/uploads/system/uploads/attachme nt_data/file/783765/BEIS-SME-Action-Plan.pdf.

Van de Vrande, V., De Jong, J. P., Vanhaverbeke, W., \& De Rochemont, M. (2009). Open innovation in SMEs: Trends, motives and management challenges. Technovation, 29(6-7), 423-437.

van Wijk, J., Zietsma, C., Dorado, S., de Bakker, F. G., \& Martí, I. (2018). Social innovation: integrating micro, meso, and macro level insights from institutional theory. Business \& Society, 0007650318789104.

Voorberg, W. H., Bekkers, V. J., \& Tummers, L. G. (2015). A systematic review of cocreation and co-production: Embarking on the social innovation journey. Public Management Review, 17(9), 1333-1357.

Walter, A., Auer, M., \& Ritter, T. (2006). The impact of network capabilities and entrepreneurial orientation on university spin-off performance. Journal of Business Venturing, 21(4), 541-567.

Wang, Y., Li, J., \& Furman, J. L. (2017). Firm performance and state innovation funding: Evidence from China's innofund program. Research Policy, 46(6), 1142-1161.

Wright, M., Lockett, A., Clarysse, B., \& Binks, M. (2006). University spin-out companies and venture capital. Research Policy, 35(4), 481-501. 
Yunus, M., Moingeon, B., \& Lehmann-Ortega, L. (2010). Building social business models:

Lessons from the Grameen experience. Long-range Planning, 43(2-3), 308-325.

Appendix A - List (alphabetical) of industries with a social mission used in this study

3D printing

Adaptive learning

AdTech

Alternative finance

Artificial Intelligence

Augmented reality

Big data

Biomass and biofuels

BYOD (Cloud data management)

Crypto-currencies

Digital security

Drones

EdTech

eHealth

Fast fashion

FinTech

Gamification

InsurTech

Internet of Things

Omni-channel retailing

Open-source software development

Precision agriculture

Preventive care

Regenerative medicine 
Robotics

Services on demand

Sharing economy

Smart homes

Social shopping

Urban farming

Virtual reality

VoIP (Cloud telecommunications)

Wearables

Appendix B - Correlations

\begin{tabular}{|l|c|c|c|c|c|c|c|}
\hline \multicolumn{1}{|c|}{ Spearman $\rho$} & 1 & 2 & 3 & 4 & 5 & 6 & 7 \\
\hline 1. accelerator & - & & & & & & \\
2. spin_off & -0.002 & - & & & & & \\
3. grants_value & 0.016 & $.259 * *$ & - & & & & \\
4. fundraisings_value & $-.126^{*}$ & $.110^{* *}$ & $.394^{* *}$ & - & & & \\
5. social_innovation & -0.004 & -0.003 & -0.006 & -0.037 & - & & \\
6. firm_size & -0.01 & $.106^{* *}$ & $.398^{* *}$ & $.716^{* *}$ & $.040^{*}$ & - & \\
7. business_stage & -0.007 & $.104^{* *}$ & $.376^{* *}$ & $.594^{* *}$ & 0.013 & $.551^{* *}$ & - \\
\hline
\end{tabular}

*Correlation is significicant at the 0.05 level (2-tailed); ** Correlation is significant at the 0.01 level (2-tailed). 


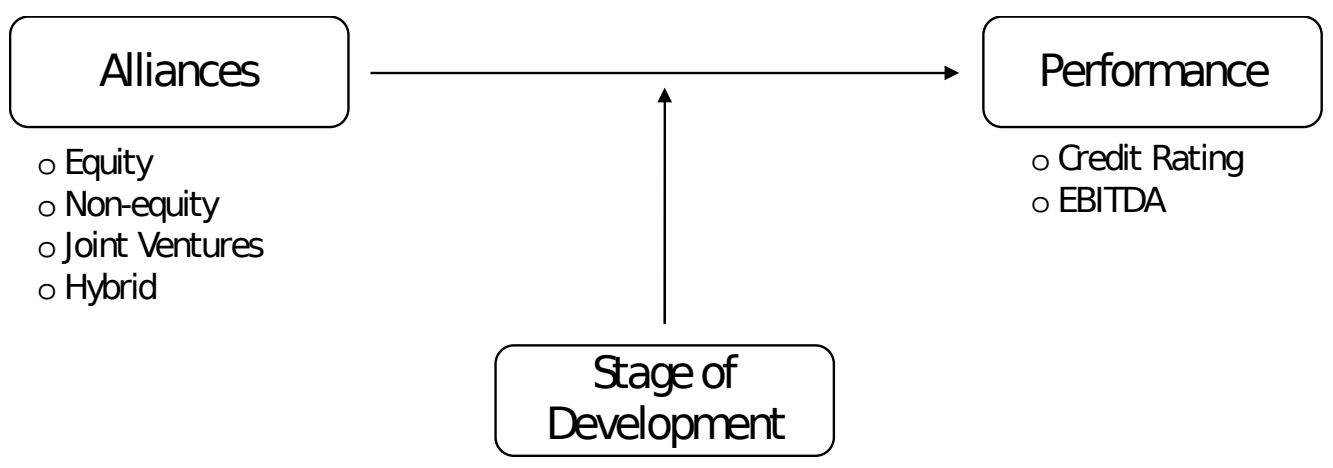

Controls: Social Innovation / Firm Size

Figure 1: Conceptual framework.

\begin{tabular}{|c|c|c|c|c|c|c|c|c|c|c|c|}
\hline \multirow{2}{*}{$\begin{array}{l}N=3,913 \\
\text { Population }=35,000\end{array}$} & \multirow{2}{*}{ Sample: N } & \multirow{2}{*}{$\begin{array}{l}\text { Strata } \\
\text { Percent }\end{array}$} & \multirow{2}{*}{$\begin{array}{l}\text { Freq. } \\
\text { Percent }\end{array}$} & \multirow{2}{*}{ Mean } & \multirow{2}{*}{ Median } & \multirow{2}{*}{$\begin{array}{c}\text { Std } \\
\text { Deviation }\end{array}$} & \multirow{2}{*}{ Min } & \multirow{2}{*}{ Max } & \multicolumn{3}{|c|}{ Percentiles } \\
\hline & & & & & & & & & 25 & 50 & 75 \\
\hline \begin{tabular}{r|} 
business_tage \\
zombie or dead \\
seed \\
growth \\
venture \\
exited \\
\end{tabular} & 3913 & 11.18 & $\begin{array}{c}22.40 \\
60.30 \\
3.20 \\
12.00 \\
2.00 \\
\end{array}$ & 1.11 & 1 & 0.95 & 0 & 4 & 1 & 1 & 1 \\
\hline \begin{tabular}{|r|} 
fim_size \\
5 employees \\
$5-9$ employees \\
$10-24$ employees \\
$25-49$ employees \\
$50-99$ employees \\
$100-249$ employees \\
$250-499$ employees \\
$500+$ +employees
\end{tabular} & 1771 & 5.06 & $\begin{array}{c}52.60 \\
20.70 \\
15.40 \\
5.80 \\
3.00 \\
1.80 \\
0.60 \\
0.20\end{array}$ & 1.95 & 1 & 1.30 & 1 & 8 & 1 & 1 & 3 \\
\hline $\begin{array}{r}\text { gender } \\
\text { female } \\
\text { male }\end{array}$ & 3256 & 9.30 & $\begin{array}{l}26.90 \\
73.10\end{array}$ & - & 1 & - & 0 & 1 & 0 & 1 & 1 \\
\hline \begin{tabular}{r|} 
fundraisings_no \\
1 \\
2 \\
3 \\
4 \\
5 \\
6 \\
7 \\
8 \\
9 \\
10 \\
12 \\
\end{tabular} & 1658 & 4.74 & $\begin{array}{c}36.10 \\
24.70 \\
16.60 \\
8.90 \\
6.20 \\
3.40 \\
2.10 \\
1.00 \\
0.80 \\
0.20 \\
0.10\end{array}$ & 2.55 & 2 & 1.79 & 1 & 12 & 1 & 2 & 3 \\
\hline $\begin{array}{r}1 \\
2 \\
3 \\
4 \\
5 \\
6 \\
7 \\
8 \\
9 \\
10 \\
11 \\
12 \\
14 \\
15 \\
16\end{array}$ & 727 & 2.08 & $\begin{array}{c}61.60 \\
18.80 \\
8.10 \\
4.40 \\
2.90 \\
1.70 \\
0.70 \\
0.60 \\
0.10 \\
0.10 \\
0.40 \\
0.10 \\
0.10 \\
0.10 \\
0.10\end{array}$ & 1.90 & 1 & 1.76 & 1 & 16 & 1 & 1 & 2 \\
\hline
\end{tabular}


Table 1: Sample Description

\begin{tabular}{|c|c|c|c|c|c|c|}
\hline \multirow{3}{*}{\begin{tabular}{|l|}
$\begin{array}{l}\text { Direct effect models la and } 1 \mathrm{~b} \\
(\mathrm{~N}=3,913)\end{array}$ \\
Predictors \\
\end{tabular}} & \multicolumn{3}{|c|}{$\begin{array}{c}\text { Model la } \\
\text { DV: Credit rating }\end{array}$} & \multicolumn{3}{|c|}{$\begin{array}{l}\text { Mocdel lb } \\
\text { DV: EBITDA }\end{array}$} \\
\hline & \multirow{2}{*}{ Beta } & \multicolumn{2}{|c|}{ Collinearity Tests } & \multirow{2}{*}{ Beta } & \multicolumn{2}{|c|}{ Collinearity Tests } \\
\hline & & TOL & $\mathrm{VF}$ & & TOL & VF \\
\hline (Constant) & - *** & & & - *** & & \\
\hline accelerator & .118 & 967 & 1.034 & $-.778 * * *$ & .024 & 1.340 \\
\hline spin_off & -.032 & 947 & 1.056 & $.511 * * *$ & .053 & 1.432 \\
\hline grants value & .032 & .945 & 1.058 & $.162 * * *$ & .792 & 1.329 \\
\hline fundraisings_value & $.234 * * *$ & .702 & 1.424 & $-1.674 * * *$ & .036 & 1.422 \\
\hline social innovation & -.083 & .934 & 1.071 & $-.114 * *$ & .351 & 1.073 \\
\hline firm_size & $.328 * * *$ & .666 & 1.501 & .765 *** & .035 & 1.329 \\
\hline \multicolumn{7}{|l|}{ Model summary } \\
\hline $\mathrm{R}$ & \multicolumn{3}{|c|}{.546} & \multicolumn{3}{|c|}{.990} \\
\hline R-sq & \multicolumn{3}{|c|}{.298} & \multicolumn{3}{|c|}{.981} \\
\hline Adj. R-sq & \multirow{2}{*}{\multicolumn{3}{|c|}{.241}} & \multicolumn{3}{|c|}{.933} \\
\hline ANOVA & & & & & & \\
\hline $\mathrm{F}$ & \multicolumn{3}{|c|}{5.173} & \multicolumn{3}{|c|}{3.648} \\
\hline df & \multicolumn{3}{|c|}{6} & \multicolumn{3}{|c|}{6} \\
\hline sig. & \multicolumn{3}{|c|}{.000} & \multicolumn{3}{|c|}{.013} \\
\hline
\end{tabular}

Table 2: Direct Effects Regression Models 1a and 1b.

\begin{tabular}{|c|c|c|c|c|c|c|}
\hline \multirow[t]{3}{*}{$\begin{array}{l}\text { Interaction effect models } 2 a \text { and } 2 b \\
(N=3,913)\end{array}$} & \multicolumn{3}{|c|}{$\begin{array}{c}\text { Model } \mathbf{2 a} \\
\text { DV: Credit rating }\end{array}$} & \multicolumn{3}{|c|}{$\begin{array}{l}\text { Modde } \mathbf{2 b} \\
\text { DV: EBITDA }\end{array}$} \\
\hline & \multirow{2}{*}{ Beta } & \multicolumn{2}{|c|}{ Collinearity Tests } & \multirow{2}{*}{ Beta } & \multicolumn{2}{|c|}{ Collinearity Tests } \\
\hline & & TOL & $\mathrm{VF}$ & & TOL & VF \\
\hline (Constant) & $-* * *$ & & & - & & \\
\hline business stage * accelerator & $.123 * * *$ & .619 & 1.614 & .012 & .419 & 2.389 \\
\hline business stage* grants_value & .016 & .723 & 1.382 & $.153 * * *$ & .597 & 1.676 \\
\hline business stage * funraisings value & $.126 * * *$ & .715 & 1.398 & $-1.115 * * *$ & .205 & 1.886 \\
\hline social_innovation & -.045 & .991 & 1.009 & .023 & .908 & 1.101 \\
\hline firm_size & $.176 * * *$ & .591 & 1.693 & .135 & .116 & 2.587 \\
\hline \multicolumn{7}{|l|}{ Model summary } \\
\hline $\mathrm{R}$ & \multicolumn{3}{|c|}{.354} & \multicolumn{3}{|c|}{.987} \\
\hline R-sq & \multicolumn{3}{|c|}{.125} & \multicolumn{3}{|c|}{.975} \\
\hline Adj. R-sq & \multicolumn{3}{|c|}{.117} & \multicolumn{3}{|c|}{.968} \\
\hline \multicolumn{7}{|l|}{ ANOVA } \\
\hline $\mathrm{F}$ & \multicolumn{3}{|c|}{14.954} & \multicolumn{3}{|c|}{138.126} \\
\hline df & \multirow{2}{*}{\multicolumn{3}{|c|}{$\begin{array}{c}5 \\
.000\end{array}$}} & \multirow{2}{*}{\multicolumn{3}{|c|}{$\begin{array}{c}5 \\
.000\end{array}$}} \\
\hline sig. & & & & & & \\
\hline
\end{tabular}

Table 3: Interaction Effects Regression Models 2a and 2b. 